\title{
Correction to: Neratinib in Early-Stage Breast Cancer: A Profile of Its Use in the EU
}

\section{Sohita Dhillon ${ }^{1}$}

Published online: 6 February 2019

(c) Springer Nature Switzerland AG 2019

\section{Correction to: Clin Drug Investig (2019) https://doi.org/10.1007/s40261-018-0741-2}

An Online First version of this article was made available online at https://rd.springer.com/article/10.1007\%2Fs40261018-0741-2 on 3 January 2019. An error was subsequently identified in the article, and the following correction should be noted:

Correction to Fig. 1 caption

The caption of Fig. 1, which previously read:

"Fig. 1 Inhibition of ER/HER2 cross-talk with neratinib plus endocrine therapy. $E$ oestrogen, $E R$ oestrogen receptor, $H R$ hormone receptor, HER2 human epidermal growth factor receptor 2"
Should read:

"Fig. 1 Inhibition of ER/HER2 cross-talk with neratinib plus endocrine therapy. $E$ oestrogen, $E R$ oestrogen receptor, $H R$ hormone receptor, HER2 human epidermal growth factor receptor 2. () Puma Biotechnology, 2018 (published with permission)"

The original article can be found online at https://doi.org/10.1007/ s40261-018-0741-2.

Sohita Dhillon

demail@ springer.com

1 Springer, Private Bag 65901, Mairangi Bay, Auckland 0754, New Zealand 